\title{
The case against active pension funds: Evidence from the Turkish Private Pension System
}

\author{
Umut Gökçen ${ }^{\mathrm{a}, 1}$, Atakan Yalçın ${ }^{\mathrm{b}, *}$ \\ a Koç University, Rumelifeneri Yolu, Sarnyer, 34450 Istanbul, Turkey \\ b Ozyegin University, Alemdag, Cekmekoy, 34794 Istanbul, Turkey
}

\section{A R T I C L E I N F O}

\section{Article history:}

Received 28 April 2014

Received in revised form 30 January 2015

Accepted 2 April 2015

Available online 10 April 2015

\section{Keywords:}

Pension funds

Active management

Herding

Pension reform

Defined contribution

\begin{abstract}
A B S T R A C T
Using data on private Turkish pension funds we show that most active managers are not able to provide performance beyond what could be achieved by passive indexing. The average fund beats its benchmark by only 26 basis points, before fees. We also observe herding behavior among managers' asset allocation decisions which can potentially explain their lack of overperformance. Our results strongly support the need for low-cost index funds in emerging market countries that are reforming their pension schemes. We further recommend regulatory oversight on the "activeness" of funds and introduction of default plans with more balanced asset allocations.
\end{abstract}

(c) 2015 Elsevier B.V. All rights reserved.

\section{Introduction}

Despite mounting evidence that retail investors are no better off investing with active funds, the allure of active investing is enduring. In a recent Wall Street Journal ${ }^{2}$ article, even Burton Malkiel, one of the most vocal proponents of passive investing, confides that he uses $10 \%$ of his investment portfolio to actively trade individual stocks. Nevertheless, he regards these focused bets as "a hobby" and states "For your serious retirement money, you don't gamble." We believe this to be sound advice and present empirical evidence on active pension funds in Turkey which supports this view. We hope that the results in this paper will prompt countries in the process of reforming their pension systems to tilt their product offerings toward passive alternatives.

Private pension funds are relatively new in Turkey and their structure allows many economic questions to be studied. Private plans are voluntary and set up as defined contributions as opposed to defined benefits which are the case for government provided pensions. As a result of these features, the money flowing into the private pension fund system represents the portfolio choices of the retail investor, and the fund manager

\footnotetext{
* Corresponding author Tel.: +90 216564 9587; fax: +90216 5649045.

E-mail addresses: ugokcen@ku.edu.tr (U. Gökçen), atakan.yalcin@ozyegin.edu.tr (A. Yalçın).

${ }^{1}$ Tel.: +90212338 1672.

2 http://online.wsj.com/news/articles/SB10001424052702304330904579137410675036086.
} 
focuses on performance without worrying about the asset/liability mismatch. The system has grown exponentially in assets under management since its inception in 2003 - with the new government subsidy introduced in 2013, the public's interest in private pension funds is greater than ever - yet ours is the first academic study on them. Other than the descriptive annual reports published by the "Pension Monitoring Center", a consortium of pension companies, there is very little information on the risk and return characteristics of individual funds. Hence how beneficial the private pension system has been and how it can further be improved are still open questions.

Using the complete universe of Turkish pension funds, we document that active funds, on average, do not overperform their self-declared benchmarks in a statistically, or economically significant way. For funds without self-declared benchmarks (categorized as "Flexible", "Mixed", or "Balanced"), the average return is below the average return on Turkish Government bonds. We perform time-series regressions with 11 asset class factors and find that fund style indexes (obtained from our data provider) do not deliver any statistically significant positive alphas, neither does the composite pension fund index representing the value-weighted portfolio of all existing funds. When we examine individual funds, a panel regression with both population and fund-specific coefficients reveals that the population alpha is not significantly different from zero (notwithstanding some funds with significantly positive alphas). Under the efficient market hypothesis this is, of course, to be expected. However, emerging markets such as Turkey are considered to be less informationally efficient than their developed counterparts in North America or Europe therefore it is surprising to find that "beating the market" is hard even for local experienced professionals.

A unique feature of our dataset due to the regulatory environment in Turkey is that it is not limited to just net asset values; we also have information on funds' portfolio composition at the asset class level. This allows us to substitute observed asset allocations in place of historical betas when we carry out a "style analysis" à la Sharpe (1992). We find 15 managers out of a total of 142 who are able to provide a positive selection return, and 9 managers who yield a negative selection return. On average, the tracking error of all funds is around 5\%, a relatively low number which suggests that many active funds might secretly be following indexes instead of making active bets on individual securities. While we cannot observe their trades in individual securities, we still find compelling evidence of herding among fund managers at the asset class level. Specifically, managers tend to revert back to the average asset allocation of their style peers from one week to the next. This effect holds strongly in all major asset classes, while controlling for deviations from the fund's declared benchmark allocations, as well as lagged returns on indexes.

One goal of our study is to aid retail investors in making better informed decisions about their pension plans. Under the current system it is the retail investors' responsibility to pick a fund when they enter the system, or change to a different fund if they are not happy with its performance at some time in the future. There is no default option that provides a balanced portfolio of different asset classes which results in an overrepresentation of government bond funds and an underrepresentation of equity funds. There is also an incredible home bias: international funds make up only $0.5 \%$ of the total net asset value in the private pension system. It is our view that considering the low levels of financial literacy in emerging market countries, relinquishing all the control about their life savings to first-time pensioners may not be ideal. Default plans based on risk preferences and the investment horizons can be offered to individuals with the option to change to different plans if they so desire.

If the investor who opts into the system picks a fund at random, our previous results imply that he or she will earn (on average) about the same as some common indexes. But how about picking funds based on past performance? We consider the implications of one simple fund picking strategy. Our example is meant to be cautionary; it is not a strategy that we recommend to retail investors. We observe the ten best performing funds at the end of each year and re-invest 1/10th of our hypothetical portfolio with them. Assuming this equal-weighted portfolio of pension funds gets rebalanced once every year for the eight years of our sample period, we find that the terminal value that this strategy yields is extremely sensitive to how funds are ranked and ultimately chosen. If funds are ranked based on their benchmark-adjusted returns, then 1000 Turkish Liras invested with this strategy grows to 2788.12 liras over the course of eight years. If however, funds are ranked according to their absolute returns, then the same strategy with the same initial investment yields only 1038.09 liras at the end of the sample period. The reason for this substantial difference comes down to the futile attempt of chasing the best performing asset classes. Ranking funds on absolute returns favors the asset classes that have recently performed well, and there is simply no persistence in returns from one year to the next at the asset class level. In fact the dismal (hypothetical) performance outlined above is a direct result of equities outperforming 
every other asset class by a large margin in 2007, and then come crashing down in 2008 , wiping out any gains to date. As this example illustrates, focusing on past performance and moving in and out of funds frequently is not beneficial to the naïve pension investor; which further supports the argument that he or she would be better served with a diversified portfolio of fixed default asset allocations.

Lastly, we remind the reader that every one of our analyses is performed on gross returns, that is, returns before fees which are currently around $2 \%$. Hence the actual returns that retail investors earn would be even less than the numbers reported here. Given these circumstances, we conclude that retail investors would be much better off with cheaper passive index funds. This is not to say that active management has no place in the pension fund industry; we clearly observe managers with outstanding performance. The issue is that such ability is rare and in reality many managers already choose not to take on many active bets in the first place, perhaps fearing underperformance. We urge the regulators to measure where on the active/passive continuum each fund stands and monitor the fee structure so that it correctly reflects the fund's cost of doing business.

\section{Literature review}

This paper mainly contributes to the literature on the performance of pension funds, an area which has attracted considerably less academic interest compared to mutual funds. This is due mostly to the scarcity of data on pension funds; there is no equivalent of CRSP mutual fund database for pension funds. Survivorship bias and representativeness are common concerns in pension fund data, nevertheless the main findings are generally in the same vein as mutual funds. The basic takeaway of the studies in the US is that pension funds "can't beat the market" and most of the return variation is attributable to the investment policy (benchmark asset allocation).

Ippolito and Turner (1987) report negative CAPM alphas net of fees, whereas Lakonishok et al. (1992) report on average $1.3 \%$ annual underperformance compared to the S\&P 500 Index, before fees. Coggin et al. (1993) provide a more nuanced view in that, if one chooses a benchmark in line with the managers' investment style (rather than the typically chosen S\&P 500), then it is possible to detect some security selection ability. Ferson and Khang (2002) find no evidence of abnormal performance in their sample of equity pension funds based on a new conditional portfolio weight based measure they develop. Most recently, Busse et al. (2010) show that the cross-sectional distribution of actual fund alphas is below their simulated counterparts, indicating it is luck rather than skill that determines abnormal performance. On the topic of performance attribution, findings from two early studies have proved to be extremely robust. Brinson et al. (1986) and Brinson et al. (1991) show that the investment policy of a fund explains more than $90 \%$ of the variation in returns. Their view is that the time and effort spent by pension plan sponsors on selecting managers is misguided, considering how little they contribute to the outcome. Ibbotson and Kaplan (2000) later confirm these findings in the timeseries, however they point out that in the cross-section of fund returns the policy return only explains $40 \%$ of the variation as opposed to $90 \%$ for the time-series, thus making the problem of manager selection far from trivial. Aglietta et al. (2012) argue that active management is more important than the asset allocation by separating the common market movements from individual asset allocations. This however, does not change the fact that for traditional asset classes such as stocks and bonds, variation in passive indexes dominates the effects of active management.

Pension funds do not fare well in other parts of the world either. Angelidis and Tessaromatis (2010) show that an average Greek pension fund loses a hypothetical return of $0.91 \%$ based on the Sharpe Ratio of the domestic equity market index. Jackowicz and Kowalewski (2012) find that the median Polish pension fund provides an alpha of $1 \%$ per annum and incidentally also charges an expense ratio of $1 \%$. Fallón et al. (2010) compare 30 active private pension funds in Columbia to passive ETFs and conclude that the ETFs would have been a better choice for the Columbian investor. In the UK, Blake et al. (1999) show that $96 \%$ of the variation in pension fund returns could be explained by the variation of "normal" return (based on long-term averages of portfolio weights). They find statistically insignificant selection returns and significantly negative market timing returns, leading them to conclude that a randomly selected pension fund would have been better off by following passive indexes. Tonks (2005) report short-term persistence among UK pension fund managers. In particular, he finds that a long position in a portfolio of fund managers that performed well over the previous 12 months and a short position of portfolio managers that performed poorly yields an annualized abnormal return of $1.56 \%$. A caveat is that this return difference does not take account of fund fees and transaction costs, which means that pension plan holders would probably not be able to take advantage of this kind of short-term persistence. 
There are several other studies that look at the non-performance aspects of delegated portfolio management. Dahlquist and Martinez (2015) show that Swedish pension fund investors do not react to past fund performance as do their mutual fund counterparts. They speculate that this might be a result of pensions being mandatory in Sweden and the mutual fund investors being more sophisticated. In contrast, Ferruz et al. (2009) find that Spanish pension fund flows are related to past performance. Parwada and Faff (2005) investigate the factors that go into manager selection for the pension plan mandates in Australia. Among the most important factors are top-quartile five-year performance and management expenses. Funke and Stadtmann (2004) discuss in detail the operations of the Thai Government Pension fund. They argue that from a diversification point of view the fund is overinvested in government bonds and underinvested in equities. Finally, Kominek (2012) and Raddatz and Schmukler (2013) investigate herding behavior among pension fund managers in Poland and in Chile, respectively. Both studies find strong evidence of herding

\section{A) Assets Under Management in Pension Funds}

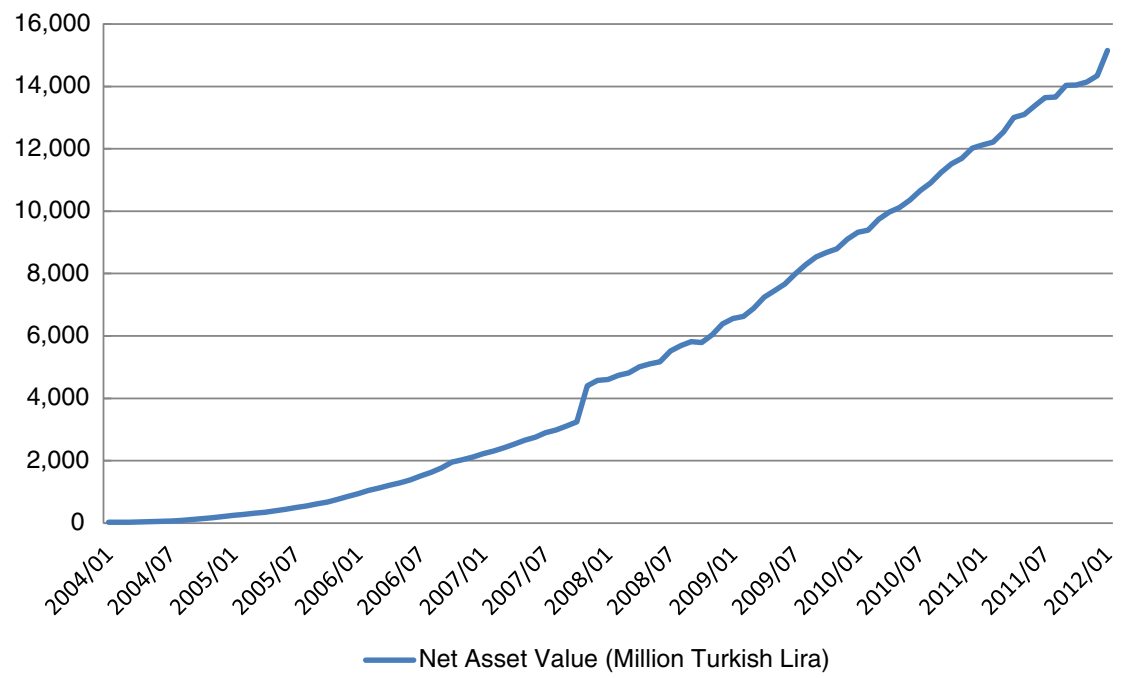

B) Fund Style Breakdown by Net Asset Value

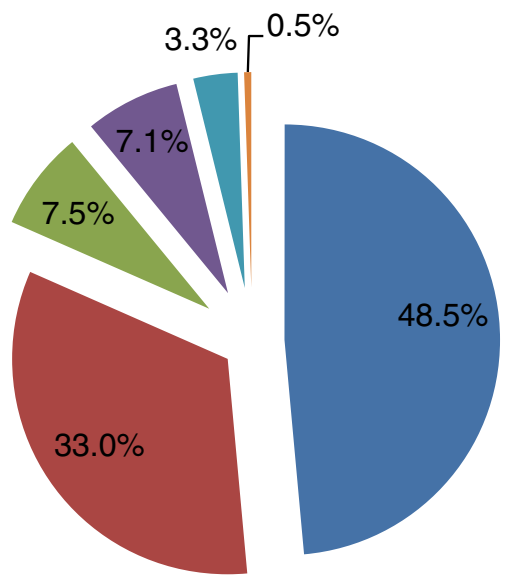

- Government Internal Debt

Balanced, Flexible, Mixed

Equity

Money Market

Government External Debt

International

Fig. 1. Overview of the pension fund industry. Panel A: assets under management in pension funds. Panel B: fund style breakdown by net asset value. 
(using different measures) and point to regulatory rules such as minimum return requirements or underperformance penalties as potential causes.

\section{Background on the Turkish Private Pension System}

The Individual Pension System (IPS) in Turkey was officially commenced on October 27, 2003. The system aims to complement the public pension system and is part of a drive to boost the domestic savings rate in the country. Participation in the IPS is voluntary and based on defined contribution plans. The contributions collected from participants are pooled in individual accounts overseen by pension companies and invested in pension funds managed by asset management companies. The participants themselves decide on portfolio allocations spanning a wide selection across asset classes provided under the terms of their IPS plans.

As of year-end 2011, there are close to 3 million participants vested in retirement plans offered by 15 different pension management companies. As can be seen in Fig. 1, Panel A, assets under management have grown rapidly to around 15 billion Turkish Liras (about 9 billion U.S. dollars at the time) from a mere 43 million in 2003. The Pension Monitoring Center (PMC) and the Undersecretariat of Treasury expect the growth to accelerate in the medium run. Moreover, the Turkish Government has introduced a set of reforms in 2012 to provide additional incentives for individuals to join the IPS. Starting in 2013, the government makes a direct contribution equal to $25 \%$ of the annual contribution made by participants themselves - capped at $25 \%$ of the annual gross minimum wage. According to the official estimates, the total assets under management are expected to surpass 115 billion Turkish Liras by the year 2020. In addition to the state subsidy, administrative and fund management fees have been significantly reduced (by the regulators) in order to make private funds more attractive. Over the course of eight years in our sample, the average fund management fee has been almost halved to about $2 \%$ of assets under management.

A typical fund mandate itemizes how an investment manager oversees allocated funds and manages the fund for a specific style. Typically, the manager gets a fixed portion of management fees collected by the pension company - augmented usually with a relatively low, symmetric performance fee. Performance is measured relative to a benchmark set by the pension company itself. For example, in a certain fund mandate we obtained from a leading Turkish pension management company, the investment manager is contracted to be paid $16 \%$ of the total annual fund management fee, with a $\pm 1.5 \%$ performance fee. That is, the manager gets 14.5 to $17.5 \%$ of the total (2\%) fund management fee depending on how well he performs relative to a benchmark. A curious fact that we observe in the data is the lack of cross-sectional variation in fund management fees within fund styles. It seems that pension management companies are not competing on the management fee front. This lack of variation makes it impossible to answer questions such as whether the best managers charge too high or too low for their services. Regardless, throughout the article, our focus is on gross fund returns before any fees.

\section{Data description}

Our pension fund data comes from RASYONET, a private data provider that is widely used in the financial industry in Turkey. RASYONET compiles its data from the regulatory filings of funds; hence the data is completely free of reporting bias and survivorship bias. We have daily observations on fund asset values, prices, gross and net returns, self-declared benchmarks, and asset allocations. The sample covers the complete time period for which the private pension fund system has existed in Turkey. In contrast to quarterly or annual reporting that is common in the US, such fine level of detailed information makes it possible to detect overperformance if it truly exists. Since there are only a few months of observations in 2003, we choose to start our sample in January 2004. The sample ends at the end of December 2011. Because daily returns are extremely noisy, we choose to work with weekly returns instead. We define weekly return as the cumulative daily return from Wednesday to Tuesday for all fund and index series.

The index data on Turkish fixed income securities comes from the "Turkish Association of Institutional Investment Managers" (TKYD), a private organization whose stated function is "to raise public awareness about institutional investment firms within the investment community by reaching larger audiences." They maintain and publish various indexes which are publicly available and widely adopted. ${ }^{3}$ For world-wide indexes we use Bloomberg. Borsa Istanbul provides the index returns for the Turkish equities.

\footnotetext{
${ }^{3}$ http://www.tkyd.org.tr/E/endexes.aspx.
} 
Funds are categorized by their investment strategies stated in their prospectus (the fund's name will also refer to the category). Some of these are self-explanatory (i.e., equity, money market), but some need explanation. If a fund declares itself to be a "Flexible" fund, it is no longer obligated to report a benchmark to the regulators and can invest in any asset class as it deems fit. Many funds naturally follow this strategy. Some funds classify themselves as "Balanced" or "Mixed" instead of "Flexible" but from a regulatory perspective they are identical. The Government External Debt and Government Internal Debt categories refer to funds that invest in the Turkish Treasury debt market, either as in Eurobonds or in Turkish Lira denominated bonds, respectively. The law requires all funds to report their asset values in Turkish Liras hence the funds that mainly hold Eurobonds have returns that behave similar to holding foreign exchange.

We drop index funds because our focus is on active management. It is however interesting to note that there exist only two index funds in our sample. Additionally, we drop the IPO month of the fund and require at least six months of return series for each fund. After these filters our sample has a total of 142 funds with the style breakdown as follows: 41 flexible funds, 20 equity funds, 24 Government External Debt funds, 30 government internal debt funds, 9 international funds, and 18 money market funds. Fig. 1 Panel B shows the breakdown according to fund net asset values.

\section{Results}

\subsection{Main hypothesis}

Under the assumption of market efficiency, active investors on average should not be able to deliver abnormal returns. The word "abnormal" presupposes an asset pricing model hence one cannot escape the jointhypothesis problem: observation of above-average returns may indicate either that the market is not efficient or that the risk adjustment is not accurate. Despite this shortcoming, "alpha" has probably become the most popular metric in assessing the performance of active managers and the literature has converged on three or four factors as reasonable proxies for systematic risks. In our case, the typically used SMB and HML factors of Fama and French (1996) are not available for the Turkish stock market. Therefore we use indexes on major asset classes as the factors in our regressions instead. The advantage of this approach is that the factors do not need to be "priced" for the model to be valid. As long as the factors account for the co-movement in fund returns, "alpha" is a meaningful measure of the return provided by the manager over and on top of what could be achieved solely by passive indexing. Our main hypothesis therefore, is that the average "alpha" is zero.

\subsection{Descriptive statistics on risk and return}

We begin our analysis by computing the average returns and standard deviations of individual funds and indexes. We report gross returns - returns before fees - hence the numbers overstate the actual return that an individual investor would have earned. However, it is the gross return that is relevant in this setting where our objective is to quantify the added value of active management.

Table 1 Panel A reports annualized cross-sectional medians of weekly return measures along with the standard deviations for individual funds. We find that the average fund has earned around 13\% per annum, with the equity funds leading the pack with $19 \%$. It is somewhat surprising that the funds in the "Flexible" category have underperformed equity funds, considering the fact that these funds are not bound by the policy allocations that restrict other funds. Managers of "Flexible" funds are free to invest in any asset class, hence have more potential for demonstrating security selection or market timing; however their returns indicate that having less restrictions do not improve performance. International funds turn out to be the worst performers overall, but keep in mind that these returns are based on the Turkish Lira and over this time period the dollar has appreciated relative to the Lira. On the face of it, all funds seem to be able to generate sizeable returns, but we will see that the picture changes when their returns are compared to that of their benchmarks.

Most funds do not fare well when compared against their benchmark returns (also referred to as "policy returns" in the literature). In the benchmark-adjusted return column we see that the median fund is only able to beat its benchmark by 26 basis points (this is not statistically different from zero based on the standard error of the mean). Even without getting into risk adjustments, factor models, etc. this simple finding immediately raises the question of why most funds do not passively follow their benchmarks. There are certainly funds which have beaten their benchmarks by a large margin, however they are the exception rather than the 
Table 1

Descriptive statistics of fund returns and indexes.

\begin{tabular}{|c|c|c|c|c|c|c|c|c|c|c|c|c|}
\hline & & Mean return & \multicolumn{2}{|c|}{ Standard deviation } & \multicolumn{2}{|c|}{ Benchmark adj. return ( $\mathrm{p} 10$ ) } & \multicolumn{3}{|c|}{ Benchmark adj. return ( $\mathrm{p} 50)$} & \multicolumn{3}{|c|}{ Benchmark adj. return (p90) } \\
\hline \multicolumn{13}{|l|}{ Panel A: individual funds } \\
\hline All funds & & 13.02 & \multicolumn{2}{|l|}{9.50} & \multicolumn{2}{|l|}{-2.09} & \multicolumn{3}{|c|}{0.26} & \multicolumn{2}{|c|}{3.45} & \\
\hline \multicolumn{2}{|l|}{ Balanced, Flexible, Mixed } & 14.07 & 9.90 & & \multicolumn{2}{|l|}{2.00} & \multicolumn{3}{|c|}{332} & & & \\
\hline Equity & & 19.11 & \multicolumn{2}{|l|}{$\begin{array}{r}9.90 \\
27.51\end{array}$} & \multicolumn{2}{|l|}{-2.47} & & \multicolumn{2}{|c|}{6.85} & \\
\hline \multicolumn{2}{|l|}{ Government External Debt } & 10.88 & \multicolumn{2}{|l|}{11.10} & -4.30 & & & & & \multicolumn{2}{|c|}{1.63} & \\
\hline \multicolumn{2}{|l|}{ Government Internal debt } & 14.39 & 3.07 & & -1.26 & & & 25 & & & 80 & \\
\hline International & & 6.07 & 12.49 & & -11.69 & & & & & & & \\
\hline Money market & & 13.21 & 0.73 & & -0.84 & & & 31 & & & 75 & \\
\hline & & & & & Mean & turn & & & & & Stal & rd deviation \\
\hline Panel B: Turkish indexes & & & & & & & & & & & & \\
\hline BIST100 & & & & & 17.78 & & & & & & 30. & \\
\hline O/N REPO & & & & & 13.70 & & & & & & 0 & \\
\hline GOVBILL & & & & & 13.14 & & & & & & 0. & \\
\hline GOVBOND & & & & & 15.79 & & & & & & 3.2 & \\
\hline GOVDEBT USD SHORT & & & & & 2.56 & & & & & & 2.2 & \\
\hline GOVDEBT USD LONG & & & & & 8.65 & & & & & & 11.5 & \\
\hline USD/YTL & & & & & 4.96 & & & & & & 15. & \\
\hline Panel C: international index & & & & & & & & & & & & \\
\hline MSCI WORLD & & & & & 1.73 & & & & & & 17. & \\
\hline MSCI EMERG & & & & & 8.41 & & & & & & 26 & \\
\hline USGOV SHORT & & & & & 2.96 & & & & & & 1. & \\
\hline GEGOV SHORT & & & & & 3.18 & & & & & & 1.2 & \\
\hline EMBI BOND USD & & & & & 8.23 & & & & & & 8. & \\
\hline & BIST100 & O/N REPO & GOVBILL & GOVBOND & $\begin{array}{l}\text { GOVDEBT } \\
\text { USD SHORT }\end{array}$ & $\begin{array}{l}\text { GOVDEBT } \\
\text { USD LONG }\end{array}$ & USD/YTL & $\begin{array}{l}\text { MSCI } \\
\text { WORLD }\end{array}$ & $\begin{array}{l}\text { MSCI } \\
\text { EMERG }\end{array}$ & $\begin{array}{l}\text { USGOV } \\
\text { SHORT }\end{array}$ & $\begin{array}{l}\text { GEGOV } \\
\text { SHORT }\end{array}$ & $\begin{array}{l}\text { EMBI } \\
\text { BOND USD }\end{array}$ \\
\hline Panel D: correlation matrix & & & & & & & & & & & & \\
\hline BIST100 & 1 & & & & & & & & & & & \\
\hline O/N REPO & 0.00 & 1 & & & & & & & & & & \\
\hline GOVBILL & 0.05 & 0.93 & 1 & & & & & & & & & \\
\hline GOVBOND & 0.51 & 0.23 & 0.36 & 1 & & & & & & & & \\
\hline GOVDEBT USD SHORT & 0.16 & 0.08 & 0.12 & 0.27 & 1 & & & & & & & \\
\hline GOVDEBT USD LONG & 0.57 & -0.01 & 0.08 & 0.63 & 0.32 & 1 & & & & & & \\
\hline USD/YTL & -0.66 & -0.01 & -0.05 & -0.60 & -0.28 & -0.70 & 1 & & & & & \\
\hline MSCI WORLD & 0.60 & -0.05 & -0.03 & 0.28 & 0.23 & 0.51 & -0.61 & 1 & & & & \\
\hline MSCI EMERG & 0.68 & -0.03 & -0.01 & 0.42 & 0.28 & 0.61 & -0.73 & 0.86 & 1 & & & \\
\hline USGOV SHORT & -0.15 & 0.10 & 0.08 & 0.02 & -0.01 & 0.06 & 0.08 & -0.23 & -0.19 & 1 & & \\
\hline GEGOV SHORT & -0.26 & 0.10 & 0.10 & 0.00 & -0.11 & -0.12 & 0.26 & -0.46 & -0.40 & 0.60 & 1 & \\
\hline EMBI BOND USD & 0.53 & -0.06 & 0.01 & 0.54 & 0.33 & 0.88 & -0.67 & 0.54 & 0.64 & 0.08 & -0.11 & 1 \\
\hline
\end{tabular}


rule; only $10 \%$ of all funds beat their benchmarks by more than $3.45 \%$. The only category of funds which have been able to beat their benchmarks in an economically significant way is equity. The median equity fund has returned $3.32 \%$ in addition to its policy return, and the top ten percentile of the managers in this group have provided more than $6.85 \%$ additional return. It is then regrettable that only $7.5 \%$ of assets under management are invested in this category (Fig. 1, Panel B). Lastly, we point out that it is the funds themselves that set up and publish their benchmark returns. We as the researchers are not the ones deciding on which benchmark indexes would be appropriate for which style of fund; hence if there is any bias in the reported numbers it should favor the fund.

Panel B reports the average returns of passive (non-tradable) indexes in the Turkish market over the same time period. The set of passive indexes that we use are the ones most frequently reported by pension funds in their stated benchmarks and cover all major asset classes (details are reported in Appendix A). The high returns earned by money market and government bond funds may surprise some readers. The high returns mostly reflect the high interest rate environment present in Turkey. Government bonds for example offer nearly $16 \%$ return (without factoring in inflation). Turkish equities offer slightly higher returns - $2 \%$ premium over the "riskfree" - yet with much higher volatility. Panel C reports some commonly used developed and emerging market indexes. The low average return of the equity indexes is a result of the financial crisis in 2008; the high returns one would have earned in the US or European stocks in the years leading up to the crisis would be completely wiped out in the subsequent years. Investors who would have chosen the safest instruments a priori, namely the US and German Treasury bills, would have paradoxically come on top during our sample period. These asset class index returns put the relatively high Turkish pension fund returns into context. Rather than rejoicing at the prospect of earning around $14 \%$ per annum by putting our money in government internal debt funds, we could do better by following a government bond index if it were a tradable security. Similarly, money market funds could boost their returns by half a percent by cutting back on trading and simply rolling over repos instead.

In Fig. 2 we plot the hypothetical growth of 1 Turkish Lira and 1 US dollar for the selected indexes. The pictures generally agree with the insights from the weekly averages reported in Table 1 . Turkish Government bonds have had the highest cumulative return, whereas world stock markets have stayed relatively flat amid significant ups and downs over the same time period. It is visually striking how closely pension fund indexes mirror these trends. The RSY_EQUITY index looks almost identical to the BIST100 index, RSY_GOVINT to GOVBOND index, and RSY_INTMIX to USD/YTL.

In Panel D of Table 1, we report the correlation matrix of the passive indexes we will be using in our regressions. The world equity markets have had relatively lower correlation in the former half of our sample, but with the onset of the global financial crisis correlations have increased and this is reflected in our period of study. For example, as shown in Table 1 Panel D, the MSCI Emerging Markets Index is highly correlated both with the Borsa Istanbul index and the MSCI World Index, with correlation coefficients of 0.68 and 0.86 , respectively. Emerging market bond indexes also seem highly correlated with each other during this time period. For instance, the JP Morgan Emerging Market bond index has a correlation of 0.88 with the index of long term Turkish Eurobonds. The highest correlation value in the table, 0.93 , is observed between the indexes of overnight repos (O/N REPO) and very short-term government bonds (GOVBILL). As a result, we chose not to include the repo index in our analysis of abnormal returns in the sections to follow. However, we would like to point out that including the repo index and excluding the short-term government bond index yield very similar results. We also ran our regressions without the world equity indexes and reached similar conclusions.

\subsection{Fund index regressions}

The dependent variables in these regressions are the fund index returns that we obtained from our data provider. The right-hand side variables are passive benchmarks covering all major asset classes. The fund

Notes to Table 1 :

Mean return is the arithmetic average of the weekly return of the fund. Standard deviation is the standard deviation of the weekly return. Benchmark adj. return is the arithmetic average of the weekly return of the fund minus the return on its declared benchmark. All statistics are given as annualized percentages. In Panel A statistics are calculated on an individual fund basis and cross-sectional medians are reported, except for Benchmark adj. return where the top and bottom decile values are also reported. Panels B and C report the mean and standard deviation of weekly returns for the Turkish and International indexes in Turkish Lira and US dollars, respectively. Panel D reports the correlation matrix of all index returns. Index definitions are given in Appendix A. 


\section{A) TURkish Asset Class Indexes}

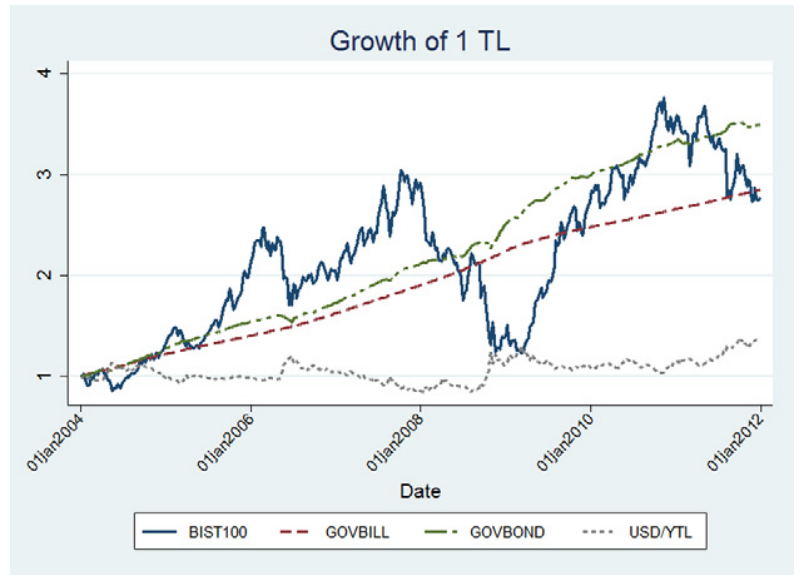

B) International AsSet CLAss IndEXES

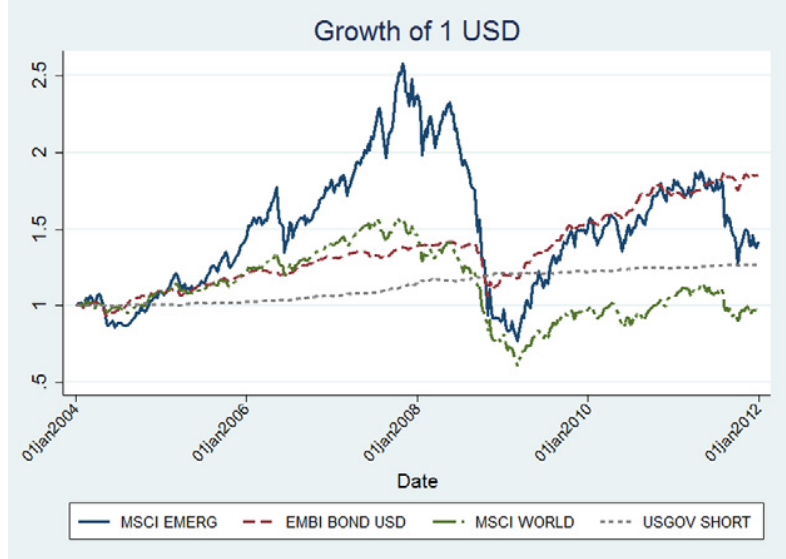

C) Pension fund Style Indexes

Growth of $1 \mathrm{TL}$

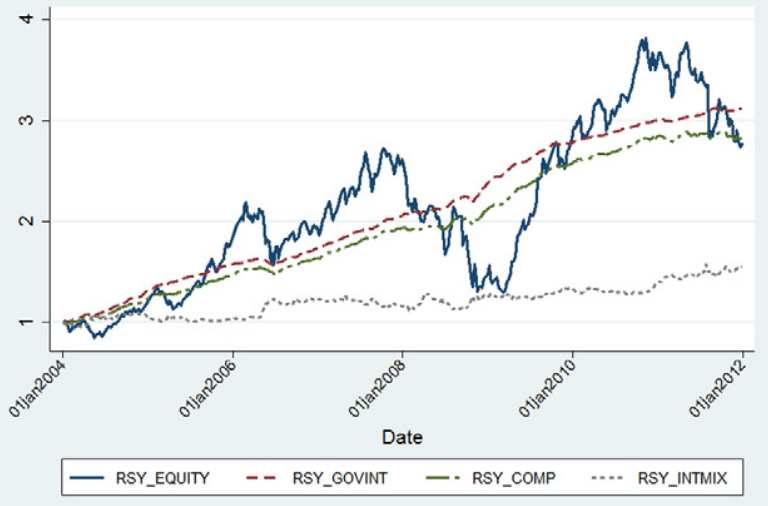

Fig. 2. Cumulative returns of select indexes. Panel A: Turkish asset class indexes. Panel B: international asset class indexes. Panel C: pension fund style indexes. 
index returns are value-weighted and hence represent the performance of the sectors of the pension fund industry rather than the performance of any individual fund or a family of funds. Even though our earlier results show that the (equal-weighted) average fund only slightly beats its benchmark, it is possible that larger funds may be overperforming while the smaller funds may be underperforming, in effect pulling the average down. If this happens to be the case, then we should be able to observe some significant alphas for these value-weighted indexes. These regressions are also useful in understanding the sensitivity of each category of funds to various asset classes. The results are presented in Table 2.

The first column represents the composite index of all funds. The point estimate of alpha is negative though not statistically significant. Columns 2 through 8 represent the fund style categories and none of them show any significantly positive alpha. In fact all alphas are negative with the exception of the money market fund index which is less than $1 \%$ per year and still not statistically significant. ${ }^{4}$ Government External Debt funds show a statistically significant negative alpha of 6.4\%. All regressions have high R-squared values between 76 and 95\% - meaning that our choice of indexes sufficiently capture the variation in fund index returns. The R-squared values that we report are consistent with the view in the literature that the majority of the variation in fund returns can be explained by asset allocation rather than security selection. This is most striking among equity funds where there is less than $5 \%$ of variation that can be attributed to active management. The "beta" coefficients that are significant for each style index are also in agreement with the declared styles of the funds. For example the equity "beta" of the equity fund index is around 0.8 , and the bond "beta" of the government internal debt fund index is around 0.9. In all, we do not observe any evidence of certain categories of funds demonstrating any better performance than the asset classes that they invest in.

\subsection{Panel regressions}

In this section we investigate individual fund alphas and try to answer the question whether the "average" fund can generate positive alpha. The dependent variable in our regressions is the individual fund's weekly return. For this model, we require funds to have at least 52 week of returns as opposed to 26, and hence end up with 136 funds out of the 142 available.

We measure the individual fund performance relative to passive benchmarks as follows:

$$
R_{i, t}=\alpha_{i}+\sum_{k=1}^{11} \beta_{k, i} R_{k, t}+\varepsilon_{i, t}
$$

where $R_{i, t}$ is fund $i$, week $t$ return and the set of $R_{k, t}$ are weekly returns on passive benchmark indexes (listed in Appendix A).

We first estimate the model in Eq. (1) using pooled OLS regression. We independently double cluster standard errors in the regression by fund and by week, and alternatively by fund-family and week. In this setup, estimated alpha and betas can be considered as overall averages for the funds included in our sample. The results are presented in Table 3, Panel A.

The overall alpha of negative 4 basis points is not statistically different from zero and echoes the lack of excess performance that we document in our analysis on the style indexes. Judging by the significance of the beta estimates, a randomly picked private pension fund in Turkey would be significantly exposed to the risk of several domestic and international asset classes.

The standard panel regression outlined above, while common in practice, does not rule out the potential impact of unobserved effects, such as manager ability, on fund returns. To address possible fund-level heterogeneity issues and to have a more robust conclusion on Turkish pension funds' abnormal returns, we reestimate Eq. (1) using a random-coefficients model in a static panel setup. To be more specific, the individual fund return is now modeled as a combination of population characteristics ( $\alpha$ and $\beta_{k}$ ) and fund-specific effects $\left(a_{\mathrm{i}}\right.$ and $\left.b_{k, i}\right)$ that are unique to a particular fund.

$$
R_{i, t}=\left(\alpha+a_{i}\right)+\sum_{k=1}^{11}\left(\beta_{k}+b_{k, i}\right) R_{k, t}+\varepsilon_{i, t}
$$

\footnotetext{
${ }^{4}$ Money market alpha happens to turn negative when we run the regression with the repo index in place of the short-term government index.
} 
Table 2

Time-series regressions of fund indexes.

\begin{tabular}{|c|c|c|c|c|c|c|c|}
\hline & \multicolumn{7}{|c|}{ Dependent variables } \\
\hline & $(1)$ & (2) & (3) & $(4)$ & (5) & (7) & (8) \\
\hline & RSY_COMP & RSY_BALANCE & RSY_EQUITY & RSY_GOVEXT & RSY_GOVINT & RSY_INTMIX & RSY_MONMKT \\
\hline BIST100 & $0.102^{* * * *}$ & $0.235^{\text {*** }}$ & $0.817^{* * *}$ & $-0.022^{*}$ & 0.002 & -0.009 & $-0.002^{*}$ \\
\hline GOVBILL & 0.255 & 0.403 & -0.078 & 0.157 & 0.089 & 0.469 & $0.807^{* * *}$ \\
\hline GOVBOND & $0.581^{* * *}$ & $0.472^{* * *}$ & 0.214 & $0.241^{\text {** }}$ & $0.938^{* * *}$ & -0.109 & $0.027^{* * *}$ \\
\hline GOVDEBT USD SHORT & -0.021 & -0.036 & -0.060 & 0.185 & $-0.060^{* *}$ & 0.024 & 0.009 \\
\hline GOVDEBT USD LONG & 0.005 & 0.004 & 0.085 & $0.658^{* * *}$ & -0.026 & 0.077 & $-0.008^{*}$ \\
\hline USD/YTL & $0.055^{\text {*** }}$ & -0.011 & $-0.081^{* *}$ & $0.812^{\text {*** }}$ & -0.009 & $0.761^{\text {*** }}$ & $-0.005^{* * *}$ \\
\hline MSCI WORLD & 0.005 & 0.012 & 0.044 & 0.009 & 0.005 & $0.309^{* * *}$ & -0.001 \\
\hline MSCI EMERG & -0.003 & -0.003 & 0.020 & 0.010 & -0.008 & $0.054^{* *}$ & 0.001 \\
\hline USGOV SHORT & $0.089^{*}$ & 0.146 & 0.065 & $0.399^{\text {** }}$ & 0.033 & $0.939^{* * *}$ & 0.013 \\
\hline GEGOV SHORT & -0.044 & 0.060 & 0.344 & $-0.458^{*}$ & 0.022 & -0.355 & -0.018 \\
\hline EMBI BOND USD & 0.006 & -0.017 & -0.117 & 0.105 & 0.019 & -0.005 & 0.002 \\
\hline CONSTANT & -1.585 & -3.686 & -0.556 & $-6.401^{* *}$ & -1.445 & -5.535 & 0.834 \\
\hline Observations & 417 & 417 & 417 & 417 & 417 & 417 & 417 \\
\hline R-squared & 0.873 & 0.907 & 0.954 & 0.896 & 0.892 & 0.768 & 0.756 \\
\hline
\end{tabular}

Dependent variables are value-weighted indexes of fund styles compiled by our data provider, RASYONET. RSY_COMP in column 1 is the composite index of all funds. RSY_BALANCE includes funds that categorize themselves as "Balanced", "Flexible", or "Mixed". RSY_EQUITY, RSY_GOVEXT and RSY_GOVINT are equity, government external (Eurobond) and internal debt funds, respectively. RSY_INTMIX includes funds that primarily invest in foreign stocks and bonds. RSY_MONMKT are money market funds. The right-hand side variables are the asset class indexes, definitions of which are given in Appendix A. White's heteroskedasticity consistent standard errors are used to determine statistical significance.

*** Represents statistical significance at the $1 \%$ level.

** Represents statistical significance at the $5 \%$ level.

* Represents statistical significance at the $10 \%$ level.

We use the random-coefficients model because it allows correction for heteroskedasticity and alleviates the impact of correlated regressors. The specification of fund-specific regression coefficients permits fundlevel divergence from population characteristics. The underlying premise of the random coefficient model is that some subset of regression parameters may vary randomly from one fund to another, thereby accounting for sources of natural heterogeneity in the population. The $\alpha$ and $\beta_{k}$ s, which are assumed to be shared by all funds, allow us to make a general statement on the population parameters.

Table 3 Panel B gives estimates of the population parameters along with t-statistics based on robust standard errors accounting for cross-serial correlation in a given week and autocorrelation in a given fund. The results are remarkably similar to those obtained using the pooled OLS regression: The overall positive alpha of 33 basis points is neither economically nor statistically significant. The average exposure to domestic and international asset classes is also qualitatively identical to the pooled OLS model.

It is possible that the alpha of 33 basis points that we report may be overstating the abnormal performance if fund managers exhibit persistence. There are in fact several studies which find persistence in fund performance over short time horizons. ${ }^{5}$ To ensure that our results on alpha are not driven by short-term persistence, we re-estimate the coefficients in Eq. (2) in a dynamic panel setup using lagged fund returns up to four weeks. Specifically, the individual fund return is now modeled as follows.

$$
R_{i, t}=\left(\alpha+a_{i}\right)+\sum_{k=1}^{11}\left(\beta_{k}+b_{k, i}\right) R_{k, t}+\sum_{n=1}^{4}\left(\Gamma_{n}+\gamma_{n, i}\right) R_{i, t-n}+\varepsilon_{i, t}
$$

where $R_{i, t}, R_{k, t}, \alpha$ and $\beta_{k}, a_{i}$ and $b_{k, i}$ are as defined before, and $R_{i, t-n}$ is lagged weekly fund return. The results in Table 3 Panel B confirm what we have already shown so far; the average pension fund in Turkey finds it

\footnotetext{
${ }^{5}$ For instance, using daily return data on 230 funds over the period 1985-1995, Bollen and Busse (2005) find significant short-term persistence in fund performance beyond momentum when short measurement horizons are used. When they employ longer measurement horizons, on the other hand, persistence disappears. In a more recent sample, Huij and Verbeek (2007) verify the existence of a short-lived performance persistence in mutual fund returns.
} 
difficult to provide above average returns. It also appears that there is some short-term persistence in fund performance, with the effects disappearing beyond the third week.

We also plot the frequency distribution of the alphas and the betas obtained from the random coefficients model using the dynamic panel setup. In Fig. 3, Panel A we can see that while the average alpha is zero, there are a number of funds with positive and negative alphas. Even though about half of the funds display a positive alpha, great performance is rare. Among the 136 funds analyzed, we found only one fund which generates an alpha above $1 \%$.

Panels B and C present the distribution of betas with respect to local and international indexes, respectively. What is immediately apparent is that most funds have at least some positive exposure to Turkish Government bonds and there is substantial variation in the levels of their exposure. In contrast, most funds have little if any exposure to international indexes. This observation should come as no surprise as we have shown previously that international funds make up only $0.5 \%$ of the total net asset value in the private pension system. The distribution of equity market betas is perhaps the most curious case. Roughly $60 \%$ of the funds have little or no exposure to Turkish equities, and the ones that do are all "defensive" (betas less than 1 ). There are in fact only 19 funds with equity betas greater than 0.5 in our sample. From an asset allocation perspective, such low levels of stock or international holdings are not likely be optimal for the average investor unless one assumes extreme levels of risk aversion. If pension funds represent the entire savings of the naïve investor, it is possible that he or she is underinvested in equities and/or international asset classes.

Based on the correlations among passive indexes there is some concern for potential collinearity. Even though the random coefficients specification mitigates the concern of correlated regressors, it does not completely eliminate it. In order to check the robustness of our conclusions, we re-estimated the coefficients in the dynamic panel regression model (Eq. (3)) using the principal components instead. Specifically, we regressed weekly individual fund returns on lagged fund returns and the first six principal components of the benchmark indexes which account for roughly $90 \%$ of the variation in the data. Our main conclusion using the principal components regression remains the same: The overall alpha of about 39 basis points is neither economically nor statistically different from zero. ${ }^{6}$

\subsection{The relation between betas and fund returns}

With the betas from the panel regression at hand, it is interesting to ask whether they explain the crosssection of fund returns. Under the APT for example, one would expect a linear relation between the risk premiums of systematic factors and the fund returns. Our asset class indexes are not direct measures of risk factors, nevertheless one can think of them as factor-mimicking portfolios which the APT allows. Hence, our objective is to determine which asset class betas are "priced" and propose links to the latent risk factors.

To this purpose we employ the Fama and MacBeth (1973) regression methodology where we estimate the time-series factor betas using the random coefficients model in Eq. (3) (dynamic panel, first-stage), and then run cross-sectional regressions of fund returns on their respective betas in each week (second-stage). Table 4 reports the time-series averages of the slope coefficients and their t-statistics. ${ }^{7}$

Column 3 in Table 4 shows that the exposure to short-term and long-term government bonds explains a significant chunk of the cross-sectional variation in pension fund returns. Both risk premium estimates are between $14 \%$ and $15 \%$ per annum, with highly significant t-statistics. The average R-squared of the specification with all the factors is close to $85 \%$ and only goes down to $78 \%$ when international factors are dropped. These results indicate that pension fund managers are largely compensated for bearing the risk of Turkish Government bonds.

A surprising result from Table 4 is that the risk premium of the stock market does not turn out to be statistically significant (although the point estimate is large and positive). As it is commonly put, CAPM beta is "flat". Because this is not a test of an asset-pricing model, the interpretation of this finding is not necessarily a rejection of the linear relation between market risk and return. Rather, this non-result tells us that pension funds are not generating their returns by taking on more stock market risk. This finding is consistent with the

\footnotetext{
${ }^{6}$ These results are available from the authors upon request.

7 The multivariate betas of the first stage are estimated using the full sample period. While it is common in the literature to use five year rolling window betas to take account of time-varying betas, our relatively short sample period (eight years) unfortunately does not allow it. Nonetheless, as Chan and Chen (1988) show, there exists a linear relation between expected returns and unconditional betas and using longer periods of data in empirical tests improves the precision of the betas estimates.
} 
Table 3

Panel regressions.

\begin{tabular}{|c|c|c|c|c|}
\hline \multicolumn{5}{|l|}{ Panel A: pooled OLS } \\
\hline & \multicolumn{2}{|c|}{$\begin{array}{l}\text { Fund-week clustered } \\
\text { Standard errors }\end{array}$} & \multicolumn{2}{|c|}{$\begin{array}{l}\text { Fund family-week clustered } \\
\text { Standard errors }\end{array}$} \\
\hline & Coeff. & $\mathrm{t}$ & Coeff. & $\mathrm{t}$ \\
\hline BIST100 & 0.159 & 5.84 & 0.159 & 15.21 \\
\hline GOVBILL & 0.355 & 3.17 & 0.355 & 2.80 \\
\hline GOVBOND & 0.275 & 4.87 & 0.275 & 5.45 \\
\hline GOVDEBT USD SHORT & 0.016 & 0.64 & 0.016 & 0.44 \\
\hline GOVDEBT USD LONG & 0.095 & 4.99 & 0.095 & 4.10 \\
\hline USD/YTL & 0.215 & 6.16 & 0.215 & 9.79 \\
\hline MSCI WORLD & 0.034 & 3.63 & 0.034 & 3.59 \\
\hline MSCI EMERG & 0.004 & 0.76 & 0.004 & 0.58 \\
\hline USGOV SHORT & 0.174 & 3.88 & 0.174 & 3.06 \\
\hline GEGOV SHORT & -0.057 & -0.72 & -0.057 & -0.67 \\
\hline EMBI BOND USD & -0.011 & -1.39 & -0.011 & -0.64 \\
\hline CONSTANT & -0.042 & -0.03 & -0.042 & -0.03 \\
\hline \multicolumn{5}{|c|}{ Panel B: random coefficients } \\
\hline & \multicolumn{2}{|c|}{ Static panel } & \multicolumn{2}{|c|}{ Dynamic panel } \\
\hline & Coeff. & $\mathrm{t}$ & Coeff. & $\mathrm{t}$ \\
\hline RETLAG1 & & & 0.023 & 4.48 \\
\hline RETLAG2 & & & 0.006 & 2.31 \\
\hline RETLAG3 & & & -0.002 & -0.44 \\
\hline RETLAG4 & & & 0.002 & 0.83 \\
\hline BIST100 & 0.164 & 6.56 & 0.163 & 6.55 \\
\hline GOVBILL & 0.282 & 2.52 & 0.278 & 2.50 \\
\hline GOVBOND & 0.319 & 6.85 & 0.313 & 6.75 \\
\hline GOVDEBT USD SHORT & 0.006 & 0.16 & -0.006 & -0.16 \\
\hline GOVDEBT USD LONG & 0.087 & 3.75 & 0.093 & 4.04 \\
\hline USD/YTL & 0.197 & 6.23 & 0.195 & 6.16 \\
\hline MSCI WORLD & 0.030 & 3.03 & 0.030 & 3.01 \\
\hline MSCI EMERG & 0.007 & 1.00 & 0.008 & 1.12 \\
\hline USGOV SHORT & 0.145 & 2.21 & 0.134 & 2.04 \\
\hline GEGOV SHORT & -0.015 & -0.20 & -0.007 & -0.10 \\
\hline EMBI BOND USD & -0.012 & -0.63 & -0.015 & -0.76 \\
\hline CONSTANT & 0.330 & 0.24 & -0.047 & -0.03 \\
\hline
\end{tabular}

This table reports panel regressions of individual fund returns on asset class index returns. Panel A is pooled OLS with standard errors clustered at the fund and time levels or at the fund family and time levels. Panel B is a random coefficients model where common population parameters are estimated (reported) along with fund-specific coefficients (unreported). CONSTANT term (alpha) is in percent per annum. Standard errors are corrected for autocorrelation in individual fund returns and cross-serial correlation in a given week. Index definitions are given in Appendix A. RETLAG in panel B refers to the coefficient on lagged return of a fund for 1, 2, 3, or 4 weeks.

distributions of market betas presented in Fig. 3, Panel B and the fact that only $7.5 \%$ of the total pension fund assets are invested in equities (Fig. 1, Panel B). We have already seen that many funds have zero exposure to the stock market, hence the cross-sectional variation in their betas is probably too small to account for the variation in their returns. This result bears an interesting resemblance to what Bali et al. (2011) show for US hedge funds, namely that market beta is not related to hedge fund returns and macroeconomic risk factors such as the default premium and inflation premium best explain the cross-sectional dispersion in hedge fund returns. We believe that ours is the first study to document such a linkage between hedge funds and pension funds. However, whether pension returns are better explained by macroeconomic factors as opposed to financial factors is an interesting question beyond the scope of this article hence we do not attempt to answer it here.

\subsection{Style versus selection}

While our previous performance analyses failed to detect a positive alpha for the average fund or the for fund industry as a whole, there are still other ways that a fund manager can add "value" which all the alphas 
might have missed. Stocks returns are extremely noisy even at the weekly frequency we use, and even a large positive alpha that would be economically significant can be eschewed as statistically insignificant. The asset factor model framework also assumes fixed factor exposures which may or may not represent how managers invest in the real world. The "style" of a fund (given by the betas on asset class indexes) might drift over time, or a manager can practice "market timing", a quick move in and out of cash at opportune times to deliver above average returns. In this section, we use a variation of the methodology in Sharpe (1992) to break

\section{A) Alphas}

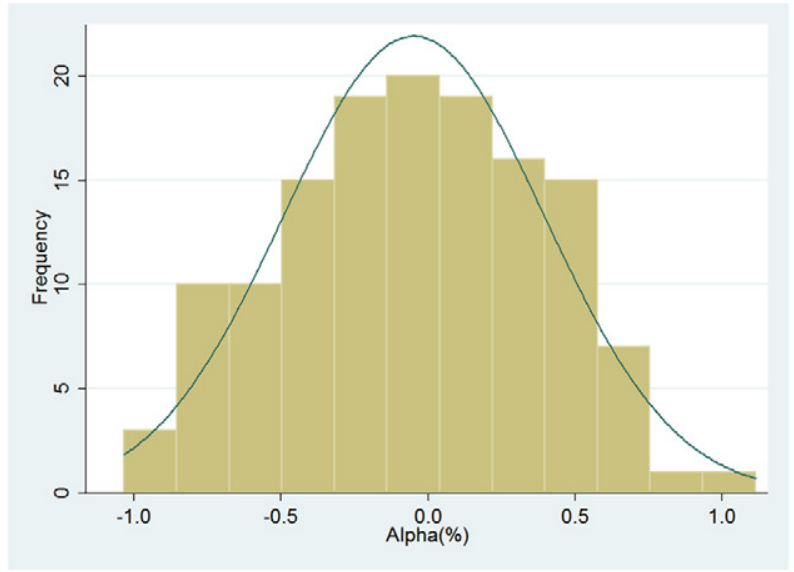

\section{B) BETAS WITH RESPECT TOTURKISH INDEXES}
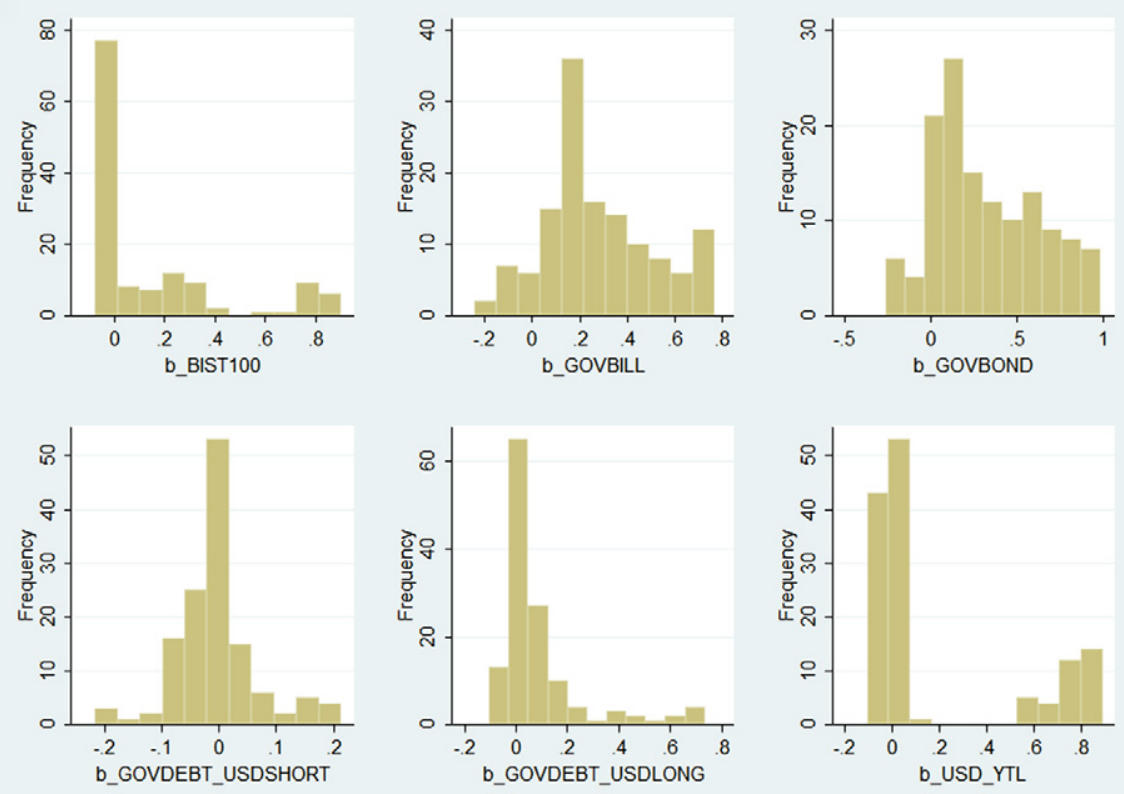

Fig. 3. Distribution of panel regression coefficients. Panel A: alphas. Panel B: betas with respect to Turkish indexes. Panel C: betas with respect to international indexes. 


\section{C) BETAS WITH RESPECT TO INTERNATIONAL INDEXES}
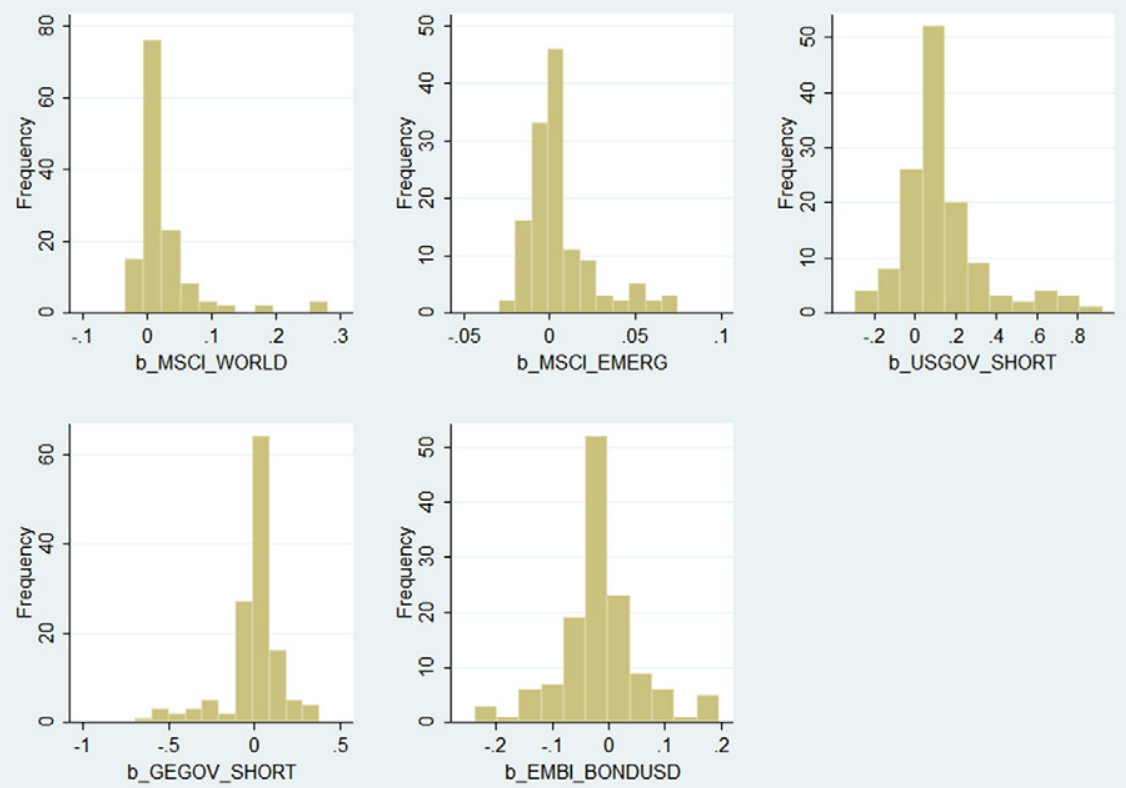

Fig. 3 (continued).

down the returns of a fund into its "style" and "selection" components. Sharpe (1992) uses the beta coefficients from five-year rolling window time-series regressions to determine a fund's style in any given month. He then subtracts the "style return" - the return that would have been realized by the asset classes multiplied by their betas - from the realized return in the subsequent month to arrive at the manager's "selection return". The data we have at hand provides us with the asset allocations of each fund at each point in time hence we do not require a regression model to estimate the fund's style return, we can simply compute this number by multiplying the fraction of a fund's portfolio in a given asset class by the return of that asset class. This feature of our data nicely side-steps the problem of estimation error in betas. Moreover, the fund's asset allocations are public information (due to government regulation). Retail investors can go to any fund's website and observe their allocations on a daily basis, thus in effect can replicate the "style" return. This makes "selection" return, defined here as the difference between the fund's realized return in a given week and its "style" return computed from one-week lagged asset weights, an extremely realistic proxy for the value added by the manager.

Table 5 reports the cross-sectional means of selection returns across various fund categories. The grand mean - the full cross-sectional average of funds' average weekly selection returns - is $0.25 \%$ per year. Government External Debt, international, and money market funds report on average a negative selection return, whereas equity funds report the largest positive selection return, $2.64 \%$. However based on the standard error of the mean of individual funds, we cannot conclude that equity funds display a statistically significant selection return. The individual fund returns are simply too volatile to determine whether the manager has any selection ability. Moreover, of the 142 funds that makes up our sample only 15 of them show statistically significant positive selection returns. This finding can be interpreted as roughly $11 \%$ of the managers adding value over passive indexing, hardly a convincing case for active investing.

Let us now focus on the second column in Table 5, the tracking error. A surprising result here is that both the flexible and equity funds, where active managers have large pools of securities to choose from, have a relatively low tracking error. The raw returns of equity funds have a standard deviation of $27.51 \%$ (Table 1 ), whereas the selection returns of equity funds have a standard deviation of $7.00 \%$. The big reduction in 
deviation indicates that it is mostly the style exposure of a fund that is contributing to its total volatility. This is consistent with the stylized fact that most of the variation in mutual fund returns is driven by factor exposures, hence asset allocation choices are the first and foremost decisions that retail investors need to make. Such close tracking of indexes by active funds has prompted the term "closet indexers" to describe some managers. The term refers to managers who charge an active management fee, but secretly follow the fund's benchmark, fearing underperformance. The low tracking error of the funds in our sample is a signal of such behavior; however it is also possible that these managers are choosing to diversify across many assets while at the same time making active bets. Cremers and Petajisto (2009) propose a new "Active Share" measure, which can distinguish closet indexers from highly active managers who also happen to make diversified stock picks. Unfortunately, we do not have stock-level portfolio holding data that is required to compute this measure. In the next section we provide other tests that may shed some light on this issue.

Finally, we report the information ratio in the third column in Table 5, which is based on the idea that it is the manager's private information (or skill in interpreting public information) that generates the return over the benchmark. By dividing this "extra" return by its standard deviation, the information ratio is said to extract the "signal" from the "noise". The average information ratio in our sample is 0.07 , which hardly goes toward implying the existence of managers with superior information. In fact, the low information ratio may be a sign that most managers in our sample are trading on noise rather than information.

Table 4

Fama-MacBeth regressions of fund returns on asset class exposures.

\begin{tabular}{lccc}
\hline & $(1)$ & $(2)$ & $(3)$ \\
\hline B_BIST100 & 13.486 & & 16.437 \\
B_GOVBILL & $(1.25)$ & $(1.47)$ \\
B_GOVBOND & 11.296 & 14.470 \\
& $(6.09)^{* * *}$ & $(7.41)^{* * *}$ \\
B_GOVDEBT USD SHORT & 11.970 & 14.732 \\
& $(5.60)^{* * *}$ & $(6.64)^{* * *}$ \\
B_GOVDEBT USD LONG & -3.947 & -0.315 \\
B_USD/YTL & $(-0.88)$ & $(-0.08)$ \\
B_MSCI WORLD & 6.189 & 6.968 \\
B_MSCI EMERG & $(1.62)$ & & $(1.78)^{*}$ \\
B_USGOV SHORT & 2.300 & & 3.562 \\
B_GEGOV SHORT & $(0.40)$ & & $(0.62)$ \\
B_EMBI BOND USD & & -6.356 & 1.554 \\
CONSTANT & & $(-1.01)$ & $(0.17)$ \\
Observations & & -7.753 & 8.675 \\
Average R-squared & & $(-0.68)$ & $(0.50)$ \\
Number of weeks & & 10.405 & 1.266 \\
\hline
\end{tabular}

This table reports coefficients from the Fama-Macbeth regressions of weekly fund returns on their corresponding asset class betas. Fund returns are annualized percentages hence the risk premium estimates in the table are in units of percent per annum. Betas are estimated in the first-stage using the random coefficients model in a dynamic panel setup (Eq. (3) in the text), using the full sample period. NeweyWest standard errors are used to compute the t-statistics (five lags).

$\mathrm{t}$-Statistics are in parentheses.

*** $\mathrm{p}<0.01$.

** $\mathrm{p}<0.05$.

$* \mathrm{p}<0.1$. 


\subsection{Herding among managers}

Why do active pension funds have low selection returns coupled with low tracking errors? One explanation is that managers "herd" in their trading behavior. This can be the rational choice in an environment where managers are evaluated relative to their peers which make underperformance a more risky proposition than otherwise it would be. Kominek (2012) develops a simple model where the manager pays a penalty for underperforming relative to the weighted average of all funds in the industry and shows that the manager will maximize his expected profit by minimizing the deviation from the average fund's portfolio. While the regulatory system in Turkey does not impose a penalty fee on underperforming managers, managers are routinely ranked with respect to other managers, and consequently face the risk of losing their mandates which are renewed every year. Therefore it feels apt to apply the empirical methodology in Kominek (2012) for testing whether managers closely follow each other in their asset allocation decisions. Specifically, the regression we run is the following:

$$
w_{i, t}-w_{i, t-1}=a_{i}+\beta_{1}\left(w_{i, t-1}-w_{\text {avg }, t-1}\right)+\beta_{2}\left(w_{i, t-1}-w_{i b n c h, t-1}\right)+\sum_{k=1}^{5} \gamma_{k} R_{k, t-1}+\varepsilon_{i, t}
$$

where $a_{i}$ is the fund specific intercept term, $w_{i}$ is the weight of a given asset class in fund i's portfolio, $w_{a v g}$ is the average weight of the asset class among all funds following the same style, $w_{i b n c h}$ is the weight of the asset class reported by the fund as its benchmark, and $R_{k}$ is a vector of asset class index returns.

The estimated coefficients from this regression determine whether a fund which has deviated from the average asset allocation of the peer group and/or from its published benchmark in one period has a tendency to reverse that decision in the next period. We include the deviation from the benchmark as a control because the regulatory system in Turkey restricts funds from deviating too far from their published benchmarks. We expect $\beta_{1}$ to be significantly negative if funds exhibit herding behavior. The regression is run as a separate panel for each of the major asset classes, including fund fixed-effects to control for heterogeneity.

Table 6 reports the regression results both with and without the asset class index returns in the specification. Lagged distance variables denote the coefficients on the previous week's deviation from the average or from the benchmark weights $\left(\beta_{1}\right.$ and $\left.\beta_{2}\right)$. Focusing on Panel A, we observe that all coefficients are statistically significant and negative for every asset class. Finding a negative coefficient on the lagged distance from the benchmark weight is somewhat expected; as mentioned before, funds are only allowed to trade in certain bands around their benchmarks. On the other hand, the negative relation between the fund's asset allocation and the lagged distance from its peer group allocation is not what one would expect if managers were acting independently of each other. We observe the strongest herding behavior in money markets, which is similar to what Kominek (2012) reports for bank deposits.

In Panel B we add in the asset class index returns to the regression model to see if managers follow signals from the dynamics of the underlying assets. If all funds were trend followers for example, one would expect the coefficient on the index return to capture this effect and render the lagged distance coefficient insignificant. What we observe instead is very little difference in the lagged distance coefficients between Panels A and $\mathrm{B}$, which means that herding behavior is robust and prevalent in all asset classes. Most of the coefficients on the asset class index returns are not significant with the exception of the repo rate. Positive coefficients found for funds that invest mostly in lira denominated government debt and money market securities imply that these funds increase their holdings when short-term interest rates rise. Conversely, funds that invest in dollar denominated government debt securities decrease their holdings, probably because they can now earn more in lira denominated repos. We also observe a significant negative coefficient on the stock market index for equity funds. This may arise if funds regularly realize their profits by selling after a market upswing, or if many of them follow value strategies. Overall, the results clearly show that managers use the information in their peer group asset allocations in forming their portfolios.

\subsection{Picking top managers}

Regardless of the type of econometric test we have employed so far, we have seen that relatively few funds were able to provide superior returns and add value. Retail investors may feel discouraged from investing with pension funds in light of these results, even though it is questionable whether they could do better on their own. If however, the retail investor were somehow able to pick the very best funds in advance, he or 
Table 5

Style analysis.

\begin{tabular}{lclcccc}
\hline & $\begin{array}{l}\text { Mean selection } \\
\text { return }\end{array}$ & $\begin{array}{l}\text { Tracking } \\
\text { error }\end{array}$ & $\begin{array}{l}\text { Information } \\
\text { ratio }\end{array}$ & $\begin{array}{l}\text { Number of } \\
\text { significant pos. }\end{array}$ & $\begin{array}{l}\text { Number of } \\
\text { significant neg. }\end{array}$ & $\begin{array}{l}\text { Total number } \\
\text { of funds }\end{array}$ \\
\hline All funds & 0.25 & 4.83 & 0.07 & 15 & 9 & 142 \\
Balanced, Flexible, Mixed & 0.80 & 4.58 & 0.21 & 4 & 0 & 41 \\
Equity & 2.64 & 7.00 & 0.37 & 0 & 0 & 20 \\
Government External Debt & -2.17 & 8.36 & -0.31 & 0 & 2 & 24 \\
Government Internal Debt & 0.88 & 1.68 & 0.48 & 10 & 3 & 0 \\
International & -1.58 & 9.24 & -0.13 & 0 & 4 & 9 \\
Money Market & -0.57 & 1.30 & -0.69 & 1 & 18 & \\
\hline
\end{tabular}

This table reports the cross-sectional averages of the fund level statistics. Mean selection return is the arithmetic average of the weekly realized return of a fund minus its "style" return, which is given by the product of the asset allocations of the fund at the end of the previous week and the returns on the corresponding asset class indexes for the present week. Tracking error is the standard deviation of the selection return. Information ratio is the mean of selection return divided by the standard deviation of selection return. Number of funds with statistically significant selection returns is determined by the standard error of the mean from the time-series of the fund's selection return. All returns are given as annualized percentages.

she would achieve above average returns. It is not our goal to provide a comprehensive list of strategies to screen managers here; nonetheless we present the outcome of one simple strategy because we feel that it carries important lessons for the retail investor. Each year we rank the funds based on either their benchmark-adjusted return or their absolute return. We then track the performance of the top 10 funds for the subsequent year. This is equivalent to a strategy of holding an equal-weighted portfolio of ten funds with annual rebalancing. We present the results in Table 7.

The average annualized return of investing with the best funds based on benchmark-adjusted returns is $18.32 \%$ which is higher than the average return on government bonds but lower than the average returns on stocks. The average return to this strategy is roughly identical to a strategy of investing half-and-half in stocks and bonds. As an alternative measure of performance, we track the growth of 1000 Turkish Liras invested at the end of 2004 in these "Top 10" funds. In Panel B, we see that by the end of 2011 the holding period return is $178.81 \%$ for the strategy using benchmarked funds, which is slightly better than both stocks and bonds individually, but slightly worse than the 50/50 mix. Many retail investors may intuitively gravitate toward funds that have performed well in the recent past, but based on these results it is difficult to recommend such a fund picking strategy. If the retail investor were to put half his money into a passive equity fund and the other half into a passive bond fund, he could have done just as well, if not better, than the best of the best managers. Given that his actual returns would further be reduced by fees, there can hardly be any justification for preferring the active funds in this scenario.

The last columns of Table 7 show the returns for the strategy of choosing the best funds based on their absolute rather than the benchmarked-adjusted return. This strategy may be even more relevant for the naïve investor who may not be familiar with the benchmarking processes and focuses only on the most recent realized return. The results highlight the disastrous implications of such behavior. The annual average return of picking the 10 best performers in each year using their absolute return as a guide is merely $3.72 \%$. More importantly, the 1000 Turkish Liras invested in 2004 would only grow to 1038 Liras after eight years with this strategy. The reason for this poor performance lies in the fact that asset factor returns drive fund returns. Almost inevitably, the top performers in any given year are determined by the performance of the asset classes. Using this absolute return ranking strategy, the retail investor ends up chasing asset classes that have performed well in the recent past. From 2004 to 2007 equity markets have performed remarkably well, hence the strategy works fine until the financial crisis in 2008. We see the hypothetical 1000 Liras first grow to 1562 and then collapse to 931, from which it never recovers. In conclusion, this strategy emphasizes the importance of being disciplined and sticking to target asset allocations. Chasing returns appears to do more damage than good when one is investing for the long term.

\section{Conclusion}

In this study we undertook a comprehensive analysis of Turkish pension funds. On any test we ran, we failed to spot abnormal performance. The average fund beats its benchmark by a much smaller margin than 
what it charges in fees and expenses. Fund indexes fail to deliver any significant positive alphas and the average alpha of individual funds is not distinguishable from zero. These underwhelming results are unlikely to be due to misspecification of the asset pricing model used to estimate alphas. We use an asset class factor model with 11 factors that include all major market indexes and explain between 76 and $95 \%$ of the variation in fund index returns. If "selection return" rather than alpha is used as a measure of performance, that is, the return in excess of the policy return based on observed asset allocations in the previous period, then only 15 funds out of 142 provide significantly positive returns. Finally, we find that top performing funds in one year are not able to repeat their success in the following year, making it an unrealistic hope for the retail investors to cherrypick those few successful managers.

Alongside fund performance, the results we present in this article also contribute to the study of market efficiency in emerging markets. It is commonly believed that emerging markets are not as informationally efficient as their counterparts in developed countries. Bekaert and Harvey (2002) provide a review of the literature which finds higher serial correlation in returns and higher excess returns to portfolio strategies based on stock characteristics in emerging markets. A more recent study, Griffin et al. (2010), warns against using the "anomaly" tests engineered in developed markets in emerging markets; nonetheless also concludes that pricing in emerging markets is less efficient based on the analysis of cross-country transaction and information production costs. Our results do not directly contradict these studies however based on the analysis of the

Table 6

Determinants of change in asset allocations.

\begin{tabular}{|c|c|c|c|c|c|}
\hline & \multicolumn{5}{|l|}{ Asset class } \\
\hline & \multirow{2}{*}{$\frac{(1)}{\text { EQUITY }}$} & \multirow{2}{*}{$\frac{(2)}{\text { GOVEXT }}$} & \multirow{2}{*}{$\frac{(3)}{\text { GOVINT }}$} & \multirow{2}{*}{$\frac{(4)}{\text { MONMKT }}$} & \multirow{2}{*}{$\frac{(5)}{\text { OTHER }}$} \\
\hline & & & & & \\
\hline \multicolumn{6}{|l|}{ Panel A } \\
\hline Lagged distance (average) & $\begin{array}{l}-0.083 \\
(-5.70)^{* * *}\end{array}$ & $\begin{array}{l}-0.049 \\
(-2.84)^{* * *}\end{array}$ & $\begin{array}{l}-0.073 \\
(-8.15)^{* * *}\end{array}$ & $\begin{array}{c}-0.184 \\
(-16.61)^{* * *}\end{array}$ & $\begin{array}{l}-0.189 \\
(-3.36)^{* * *}\end{array}$ \\
\hline Lagged distance (benchmark) & $\begin{array}{l}-0.205 \\
(-8.81)^{* * *}\end{array}$ & $\begin{array}{l}-0.172 \\
(-4.82)^{* * *}\end{array}$ & $\begin{array}{l}-0.056 \\
(-6.54)^{* * *}\end{array}$ & $\begin{array}{c}-0.111 \\
(-11.11)^{* * *}\end{array}$ & $\begin{array}{l}-0.035 \\
(-2.53)^{* *}\end{array}$ \\
\hline CONSTANT & $\begin{array}{l}0.002 \\
(2.11)^{* *}\end{array}$ & $\begin{array}{l}-0.011 \\
(-2.75)^{* * *}\end{array}$ & $\begin{array}{l}0.006 \\
(8.46)^{\text {*** }}\end{array}$ & $\begin{array}{l}-0.004 \\
(-8.73)^{* * *}\end{array}$ & $\begin{array}{l}0.011 \\
(4.98)^{* * *}\end{array}$ \\
\hline Observations & 11,726 & 6851 & 26,179 & 32,840 & 12,649 \\
\hline R-squared & $13.70 \%$ & $11.96 \%$ & $6.58 \%$ & $14.00 \%$ & $12.03 \%$ \\
\hline \multicolumn{6}{|l|}{ Panel B } \\
\hline Lagged distance (average) & $\begin{array}{l}-0.084 \\
(-5.64)^{* * *}\end{array}$ & $\begin{array}{l}-0.048 \\
(-2.76)^{* * *}\end{array}$ & $\begin{array}{l}-0.071 \\
(-7.82)^{\text {*** }}\end{array}$ & $\begin{array}{c}-0.183 \\
(-16.36)^{* * *}\end{array}$ & $\begin{array}{l}-0.172 \\
(-3.24)^{* * *}\end{array}$ \\
\hline Lagged distance (benchmark) & $\begin{array}{l}-0.203 \\
(-8.68)^{* * *}\end{array}$ & $\begin{array}{l}-0.184 \\
(-5.01)^{* * *}\end{array}$ & $\begin{array}{l}-0.060 \\
(-7.03)^{* * *}\end{array}$ & $\begin{array}{c}-0.114 \\
(-11.05)^{* * *}\end{array}$ & $\begin{array}{l}-0.051 \\
(-2.36)^{* *}\end{array}$ \\
\hline BIST100 & $\begin{array}{l}-0.046 \\
(-2.52)^{* *}\end{array}$ & $\begin{array}{c}0.014 \\
(0.37)\end{array}$ & $\begin{array}{c}0.036 \\
(1.85)^{*}\end{array}$ & $\begin{array}{l}-0.009 \\
(-0.61)\end{array}$ & $\begin{array}{l}-0.004 \\
(-0.29)\end{array}$ \\
\hline O/N REPO & $\begin{array}{c}0.144 \\
(0.20)\end{array}$ & $\begin{array}{l}-6.530 \\
(-5.03)^{* * *}\end{array}$ & $\begin{array}{l}2.770 \\
(4.15)^{\text {*** }}\end{array}$ & $\begin{array}{c}1.648 \\
(3.45)^{\text {*** }}\end{array}$ & $\begin{array}{l}-1.363 \\
(-1.35)\end{array}$ \\
\hline MSCI WORLD & $\begin{array}{l}-0.004 \\
(-0.14)\end{array}$ & $\begin{array}{l}-0.023 \\
(-0.43)\end{array}$ & $\begin{array}{l}-0.008 \\
(-0.31)\end{array}$ & $\begin{array}{c}0.009 \\
(0.43)\end{array}$ & $\begin{array}{c}0.024 \\
(0.67)\end{array}$ \\
\hline USD/YTL & $\begin{array}{l}-0.011 \\
(-0.31)\end{array}$ & $\begin{array}{r}0.027 \\
(0.38)\end{array}$ & $\begin{array}{r}0.020 \\
(0.55)\end{array}$ & $\begin{array}{l}-0.009 \\
(-0.35)\end{array}$ & $\begin{array}{l}-0.023 \\
(-0.74)\end{array}$ \\
\hline CONSTANT & $\begin{array}{r}0.002 \\
(1.22)\end{array}$ & $\begin{array}{c}0.004 \\
(0.88)\end{array}$ & $\begin{array}{r}0.000 \\
(-0.36)\end{array}$ & $\begin{array}{l}-0.008 \\
(-7.25)^{* * *}\end{array}$ & $\begin{array}{c}0.015 \\
(3.41)^{* * *}\end{array}$ \\
\hline Observations & 11,726 & 6851 & 26,179 & 32,840 & 12,649 \\
\hline R-squared & $13.86 \%$ & $12.47 \%$ & $6.74 \%$ & $14.07 \%$ & $12.15 \%$ \\
\hline
\end{tabular}

The dependent variable is the change in a fund's asset allocation for a given asset class over one period (week). Each column represents a separate regression for each asset class and all specifications include fund fixed effects (coefficients suppressed). Lagged distance (average) is the difference between a fund's percentage asset allocation in a given asset class and the average of all funds sharing the same style. Lagged distance (benchmark) is the difference between a fund's percentage asset allocation in a given asset class and its declared benchmark. All index returns are lagged by one week. Standard errors are clustered by time (week).

Robust t-statistics are in parentheses.

*** $\mathrm{p}<0.01$.

** $\mathrm{p}<0.05$.

$* \mathrm{p}<0.1$. 
performance of active pension funds we cannot reject the null hypothesis that capital markets (in Turkey) are efficient. Nevertheless it is important to remember that failing to reject the efficiency hypothesis is not the same as accepting it. As we have shown, managers tend to herd in their asset allocation choices. The fear of underperformance may be overruling their incentive to take risks and make active bets. In addition, shortsale and leverage constraints can also cause prices to deviate from fundamentals.

There are important policy implications of our findings. Remembering that the Turkish Private Pension System is based on defined-contribution plans, the underperformance of many fund managers is putting individuals' retirement savings in jeopardy. It is also important to note that the passive indexes used in our study are not directly investable, therefore the retail investor does not have much choice other than investing in one (or several) of the available active funds. Passive funds which track broad asset class indexes at a low cost are a desperately needed commodity in Turkey. The policy makers have so far focused on reducing fees and providing more flexibility to retail investors in switching between retirement plans. However, the average expense ratio is still relatively high compared to the US and shows very little cross-sectional variation. Indexing is a fail-safe mechanism to reduce fund fees. Based on the results of this study, we have come to believe that pension plan contributors would be much better served with lower-cost passive alternatives, in addition to the active funds currently available. As far as what the appropriate management fee should be, we do not offer a simple number. We think there is a need to distinguish truly active funds from those possibly in disguise. Regulators could require funds to be more transparent in terms of their choice of active and passive strategies. In addition, fund management fees in a given style could be partially tied to an objective measure such as an active share index.

Finally, we believe that retail investors need more guidance in making better informed decisions about their pension plans. Our results show that the average investor is heavily skewed toward holding short and long term government fixed income securities and shies away from asset classes such as domestic and foreign equities. As a first step in serving investors better, pension management companies could be allowed to advise

Table 7

Subsequent performance of the top 10 funds.

\begin{tabular}{|c|c|c|c|c|c|c|}
\hline & O/N REPO & Bonds & Stocks & $\begin{array}{l}50 / 50 \\
\text { Stocks/Bonds }\end{array}$ & $\begin{array}{l}\text { Top } 10 \\
\text { Benchmark adj. }\end{array}$ & $\begin{array}{l}\text { Top } 10 \\
\text { Absolute return }\end{array}$ \\
\hline \multicolumn{7}{|c|}{ Panel A: realized annual returns } \\
\hline 2004 & 24.59 & 27.97 & 36.31 & 32.14 & - & - \\
\hline 2005 & 16.27 & 21.06 & 56.47 & 38.76 & 17.13 & 27.44 \\
\hline 2006 & 17.48 & 12.13 & 0.26 & 6.20 & 8.63 & 6.76 \\
\hline 2007 & 19.18 & 22.75 & 41.98 & 32.36 & 30.81 & 14.84 \\
\hline 2008 & 17.45 & 18.51 & -52.45 & -16.97 & -1.50 & -40.43 \\
\hline 2009 & 9.68 & 19.10 & 96.08 & 57.59 & 61.61 & 6.26 \\
\hline 2010 & 6.89 & 11.57 & 28.30 & 19.94 & 31.54 & 31.21 \\
\hline 2011 & 7.26 & 5.04 & -20.89 & -7.93 & -20.00 & -20.00 \\
\hline Average & 13.46 & 15.74 & 21.39 & 18.56 & 18.32 & 3.72 \\
\hline \multicolumn{7}{|c|}{ Panel B: growth of 1000 YTL } \\
\hline 2004 & 1000.00 & 1000.00 & 1000.00 & 1000.00 & 1000.00 & 1000.00 \\
\hline 2005 & 1162.70 & 1210.55 & 1564.65 & 1387.60 & 1171.28 & 1274.38 \\
\hline 2006 & 1365.93 & 1357.39 & 1568.73 & 1473.57 & 1272.36 & 1360.52 \\
\hline 2007 & 1627.88 & 1666.22 & 2227.25 & 1950.49 & 1664.35 & 1562.38 \\
\hline 2008 & 1911.99 & 1974.60 & 1059.16 & 1619.51 & 1639.43 & 930.73 \\
\hline 2009 & 2097.01 & 2351.73 & 2076.77 & 2552.15 & 2649.49 & 988.96 \\
\hline 2010 & 2241.47 & 2623.84 & 2664.52 & 3060.94 & 3485.07 & 1297.58 \\
\hline 2011 & 2404.23 & 2756.07 & 2107.86 & 2818.33 & 2788.12 & 1038.09 \\
\hline HPR (\%) & 140.42 & 175.61 & 110.79 & 181.83 & 178.81 & 3.81 \\
\hline
\end{tabular}

This table reports the returns from a trading strategy that involves buying the top 10 funds at the end of each year and holding them for one year. Returns in a given year are the equal-weighted buy-and-hold returns of the portfolio of funds who were the previous year's top performers. The top 10 status is either based on benchmark-adjusted returns or gross returns. The buy-and-hold strategy is applied separately for these two groups. Annual repo rate is the daily overnight repo rate compounded over a year. Bonds indicate the annual return on the Turkish Government bonds index, Stocks indicate the annual return on the Borsa Istanbul 100 index. 50/50 Stocks/Bonds indicate an equal weighted portfolio of these two indexes. Panel A reports annual realized returns along with the average for the sample period in the bottom row. Panel B reports the growth of 1000 Turkish Liras invested at the end of 2004 using the realized returns from Panel A, along with the terminal value of the investment at the end of 2011. Returns are given as annualized percentages. 
on asset allocation choices to a certain extent (under the current regulatory environment they are banned from doing so). A possible way forward could be to devise default plans for representative investors with certain risk profiles. These could be based on demographic information and need not be set in stone. Individual investors could still have the option to change actual asset allocations at any time.

\section{Appendix A}

\section{A.1. Index definitions}

BIST100: A value-weighted index of the 100 largest stocks that trade on Borsa Istanbul.

O/N REPO: A volume-weighted index of overnight repurchase/reverse repurchase agreements that take place on Borsa Istanbul.

GOVBILL: Index of short-term Turkish Government bonds. Securities need to have less than 60 days until maturity to be included in the index and take on weights that are inversely proportional to the difference between the days left until maturity and 30 .

GOVBOND: A value-weighted index that contains all Turkish Government bonds regardless of maturity. GOVDEBT USD SHORT: A value-weighted index of Turkish Government bonds denominated in US dollars issued in the local market with maturities less than 2 years.

GOVDEBT USD LONG: A value-weighted index of Eurobonds denominated in US dollars and issued by the Turkish Government with maturities up to 30 years.

USD/YTL: An index that tracks the return of the US dollar/Turkish Lira exchange rate.

MSCI WORLD: MSCI World Index. Includes a collection of stocks from 24 developed markets.

MSCI EMERG: MSCI Emerging Markets Index. Includes a collection of stocks from 21 emerging markets. USGOV SHORT: Bloomberg/EFFAS Government Bond Index that tracks US Treasuries with 1 to 3 year maturities.

GEGOV SHORT: Bloomberg/EFFAS Government Bond Index that tracks German Government treasuries with 1 to 3 year maturities.

EMBI BOND USD: JP Morgan EMBI Global Total Return Index. The index covers liquid US dollar denominated debt instruments from 27 emerging market countries.

\section{References}

Aglietta, Michel, Brière, Marie, Rigot, Sandra, Signori, Ombretta, 2012. Rehabilitating the role of active management for pension funds. J. Bank. Financ. 36, 2565-2574.

Angelidis, Timotheos, Tessaromatis, Nikolaos, 2010. The efficiency of Greek public pension fund portfolios. J. Bank. Financ. 34, 2158-2167.

Bali, Turan G., Brown, Stephen J., Onur Caglayan, Mustafa, 2011. Do hedge funds' exposures to risk factors predict their future returns? J. Financ. Econ. 101, 36-68.

Bekaert, Geert, Harvey, Campbell R., 2002. Research in emerging markets finance: looking to the future. Emerg. Mark. Rev. 3, 429-448.

Blake, David, Lehmann, Bruce N., Timmermann, Allan, 1999. Asset allocation dynamics and pension fund performance. J. Bus. 72 , 429-461.

Bollen, Nicolas P.B., Busse, Jeffrey A., 2005. Short-term persistence in mutual fund performance. Rev. Financ. Stud. 18, 569-597.

Brinson, Gary P., Hood, L. Randolph, Beebower, Gilbert L., 1986. Determinants of portfolio performance. Financ. Anal. J. 39-44.

Brinson, Gary P., Singer, Brian D., Beebower, Gilbert L., 1991. Determinants of portfolio performance II: an update. Financ. Anal. J. 40-48.

Busse, Jeffrey A., Goyal, Amit, Wahal, Sunil, 2010. Performance and persistence in institutional investment management. J. Financ. 65, 765-790.

Chan, K.C., Chen, Nai-Fu, 1988. An unconditional asset-pricing test and the role of firm size as an instrumental variable for risk. J. Financ. 43, 309-325.

Coggin, T. Daniel, Fabozzi, Frank J., Rahman, Shafiqur, 1993. The investment performance of US equity pension fund managers: an empirical investigation. J. Financ. 48, 1039-1055.

Cremers, K.J. Martijn, Petajisto, Antti, 2009. How active is your fund manager? A new measure that predicts performance. Rev. Financ. Stud. 22, 3329-3365.

Dahlquist, Magnus, Martinez, José Vicente, 2015. Investor inattention: a hidden cost of choice in pension plans? Eur. Financ. Manag. 21 (1), 1-19.

Fallón, Edgardo Cayón, Rojas, Santo, Di, Tomás Ricardo, Peña, Camilo Roncancio, 2010. Evidence of active management of private voluntary pension funds in Colombia: a performance analysis using proxy ETFs. Estud. Gerenc. 26, 13-38.

Fama, Eugene F., French, Kenneth R., 1996. Multifactor explanations of asset pricing anomalies. J. Financ. 51, 55-84.

Fama, Eugene F., MacBeth, James D., 1973. Risk, return, and equilibrium: empirical tests. J. Polit. Econ. 81, 607-636.

Ferruz, Luis, Vicente, Luis, Andreu, Laura, 2009. Performance persistence and its influence on money and investor flows into Spanish pension plans. Rev. Quant. Finan. Acc. 32, 85-100. 
Ferson, Wayne, Khang, Kenneth, 2002. Conditional performance measurement using portfolio weights: evidence for pension funds. J. Financ. Econ. 65, 249-282.

Funke, Katja, Stadtmann, Georg, 2004. Operations of a pension fund after the Asian crisis: the Thai experience. Asian Econ. J. 18, 439-470.

Griffin, John M., Kelly, Patrick J., Nardari, Federico, 2010. Do market efficiency measures yield correct inferences? A comparison of developed and emerging markets. Rev. Financ. Stud. 23, 3225-3277.

Huij, Joop, Verbeek, Marno, 2007. Cross-sectional learning and short-run persistence in mutual fund performance. J. Bank. Financ. 31, 973-997.

Ibbotson, Roger G., Kaplan, Paul D., 2000. Does asset allocation policy explain 40, 90, or 100 percent of performance? Financ. Anal. J. 26-33.

Ippolito, Richard A., Turner, John A., 1987. Turnover, fees and pension plan performance. Financ. Anal. J. 16-26.

Jackowicz, Krzysztof, Kowalewski, Oskar, 2012. Crisis, internal governance mechanisms and pension fund performance: evidence from Poland. Emerg. Mark. Rev. 13 (4), 493-515.

Kominek, Zbigniew, 2012. Regulatory induced herding? Evidence from Polish pension funds. Econ. Chang. Restruct. 45, 97-119.

Lakonishok, Josef, Shleifer, Andrei, Vishny, Robert W., 1992. The structure and performance of the money management industry. Brook. Pap. Econ. Act. 339-391.

Parwada, Jerry T., Faff, Robert W., 2005. Pension plan investment management mandates: an empirical analysis of manager selection. J. Financ. Serv. Res. 27, 77-98.

Raddatz, Claudio, Schmukler, Sergio L., 2013. Deconstructing herding: evidence from pension fund investment behavior. J. Financ. Serv. Res. 43, 99-126.

Sharpe, William F., 1992. Asset allocation: management style and performance measurement. J. Portf. Manag. 18, 7-19.

Tonks, Ian, 2005. Performance persistence of pension-fund managers. J. Bus. 78, 1917-1942. 